\title{
Do exporters really pay higher wages? \\ First evidence from German linked employer-employee data
}

\section{Thorsten Schank $^{\mathrm{a}}$, Claus Schnabel $^{\mathrm{b}}$, and Joachim Wagner ${ }^{*}$}

[First version: June 2004; revised March 2005]

\begin{abstract}
: 21 studies using data from 22 highly developed, developing, and less developed countries document that average wages in exporting firms are higher than in non-exporting firms from the same industry and region. The existence of these so-called exporter wage premia is one of the stylized facts found in the emerging literature on the microeconometrics of international trade. This paper uses a large and rich set of linked employer-employee data from Germany to demonstrate that these premia become smaller but do not completely vanish when observable and unobservable characteristics of the employees and of the work place are controlled for.
\end{abstract}

Keywords: Exports, wages, exporter wage premia, linked employer-employee data, Germany

JEL-Classification: F10, D21, L60

Acknowledgements: We thank Mark Roberts and participants at the European Trade Study Group ETSG conference in Nottingham in September 2004 for extremely helpful comments that guided us in the revision of an earlier version which circulates as IZA Discussion Paper No. 1185 since June 2004. Many thanks also to Susanne Rässler and Hermann Gartner for helpful discussions and for providing their (unpublished) multiple imputation algorithm, and to Manfred Antoni for technical assistance.

\footnotetext{
a Thorsten Schank, Friedrich-Alexander-Universität Erlangen-Nürnberg, Lehrstuhl für Arbeitsmarkt- und Regionalpolitik, Lange Gasse 20, D-90403 Nürnberg, thorsten.schank@wiso.uni-erlangen.de.

b Claus Schnabel, Friedrich-Alexander-Universität Erlangen-Nürnberg, Lehrstuhl für Arbeitsmarkt- und Regionalpolitik, Lange Gasse 20, D-90403 Nürnberg, claus.schnabel@wiso.uni-erlangen.de.

$\mathrm{c}^{\star}$ Joachim Wagner, Universität Lüneburg, Institut für Volkswirtschaftslehre, Campus 4.210, D-21332 Lueneburg, wagner@uni-lueneburg.de.
} 


\section{Motivation}

Ten years ago Bernard and Jensen (1995) published a Brookings paper on "Exporters, Jobs, and Wages in U.S. Manufacturing" that used hundreds of thousands of plant level data to provide facts and figures on exporting plants compared to their non-exporting counter-parts. One of the new and exciting findings documented in this paper is that exporters tend to pay higher wages and benefits: Average wages and benefits (per worker, per production worker, and per non-production worker) are higher in exporting plants than in non-exporting plants of all size classes. Exporter wage premia are statistically significant for all categories of wages and benefits after controlling for capital per worker, size of plant, multi-plant dummy, industry, year, plant age, and region. Coefficients of exporter status dummies are statistically significant in fixed effects regressions controlling for capital per worker, hours per worker, size of plant, and year.

The Bernard and Jensen (1995) paper started a literature. A synopsis of 21 studies covering 22 different countries from highly developed economies like the U.S., Germany, and Sweden, and emerging economies like Taiwan, Korea, and Mexico, to transition countries (Estonia, Slovenia) and least developed SubSaharan African economies like Burundi or Ethiopia is provided in an Appendix Table. The empirical strategies used in these papers replicate (sometimes only partly) the approach introduced by Bernard and Jensen, and the results regarding the exporter wage premia are broadly consistent with the findings from the pioneering study.

An open question not dealt with in this literature is whether these exporter wage premia do indeed indicate that exporting plants pay higher wages in the sense that comparable workers are better paid when working on a comparable work place for an exporter, i.e. ceteris paribus. Given that all the empirical studies listed in Appendix 1 use average data at the plant or firm level, individual characteristics of the workers that might influence their productivity (and, therefore, their wages) cannot be taken into account, and certain characteristics of the work place that might call for compensating wage differentials are not represented adequately. This shortcoming has been recognized from the outset: Commenting on the presentation of the paper by Bernard and Jensen, Robert Z. Lawrence argued that "the impact of exports, while positive and statistically significant, is considerably reduced once the effects of capital intensity, industry, plant scale, and location are controlled for. One suspects, moreover, that the premiums would be even further reduced if the authors were able to control for worker characteristics. Thus the 
wage benefits that are attributable solely to exporting appear to be rather small." (Bernard and Jensen 1995, p. 113f.)

Besides providing a synopsis of the literature on exporter wage premia this paper contributes to the literature by testing for the existence of these premia when observable and unobservable individual characteristics of the employees and the work place are controlled for using a rich German linked employer-employee panel data set. The rest of the paper is organized as follows: Section 2 introduces the data set while section 3 replicates the now standard approach using plant-level data. Section 4 provides results for exporter wage premia based on linked employer-employee data using information for both individual workers and the plants they are working in. Section 5 concludes.

\section{The linked employer-employee data set}

The use of matched employer-employee data has recently become popular as it allows a more detailed analysis of economic relationships. In particular, various analyses of the labor market can benefit from the availability of employeremployee data. ${ }^{1}$ In this paper, we use the LIAB, which combines the employment statistics of the German Federal Labor Services with plant level data from the IAB Establishment Panel.

The employment statistics (cf. Bender, Haas and Klose 2000) cover all employees and trainees subject to social security. They exclude, among others, the selfemployed, family workers, a subgroup of civil servants ("Beamte"), students enrolled in higher education and those in marginal employment. The employment statistics cover nearly 80 percent of all employed persons in western Germany and about 85 percent in eastern Germany. They are collected by the social insurance institutions for their purposes according to a procedure introduced in 1973 and are made available to the Federal Employment Services. Notifications are prescribed at the beginning and at the end of a person's employment in a plant. In addition an annual report for each employee is compulsory at the end of a year. Misreporting is legally sanctioned. The employment statistics contain information on an employee's occupation, the occupational status, and gross earnings up to the contribution assessment ceiling, and on individual characteristics like sex, age,

\footnotetext{
${ }^{1}$ A survey of analyses using matched employer-employee data sets can be found in Abowd and Kramarz (1999).
} 
nationality, marital status, and qualification. Each personnel record also contains the establishment identifier, the industry, and the size of the plant.

Starting in 1993, the IAB Establishment Panel (cf. Kölling 2000) is drawn from a stratified sample of the plants included in the employment statistics, where the strata are defined over industries and plant sizes (large plants are oversampled), but the sampling within each cell is random. In 1993, the sample started with 4,265 plants, covering 0.27 percent of all plants in western Germany (2 million) and 11 percent of total employment (29 million). In 1996, the eastern German establishment panel started with 4,313 establishments representing 1.10 percent of all plants $(391,000)$ and 11 percent of total employment (6 million). The IAB Establishment Panel has been set up for the needs of the Federal Labor Services to provide further information about the demand side of the labor market. Therefore, detailed information on the composition of the workforce and its development through time constitutes a major part of the questionnaire. Further questions include information on training and further education, wages, working time, business activities, establishment policies, and general information about the plant. Other topics, for instance, questions on innovations or the flexibility of labor, are asked biannually or triannually.

The $L I A B$ is created by linking the employment statistics and the IAB Establishment Panel through a plant identifier which is available in both data sets. ${ }^{2}$ This matched employer-employee data set, which is unique for Germany, currently comprises the years 1993 to 1997. Since precise information on the collective bargaining regime of plants (needed for the imputation of wage data) is not available before 1995 and since we employ lags of investment, we can only make use of the waves 1995 to 1997 . We exclude establishments that are located in the eastern part of Germany since the economic situation (and the level of wages) in post-communist eastern Germany still differs considerably from that in western Germany. Also, we focus on the manufacturing sector since exports are only of minor importance in the service sector. Therefore, in the regressions we end up with a sample of $1,855,034$ observations of 918,149 employees in 1,262 establishments.

\footnotetext{
${ }^{2}$ The LIAB data are confidential but not exclusive. They are available for non-commercial research by visiting the data access center of the German Federal Labor Services at the IAB in Nuremberg, Germany. Researchers interested in replications or extensions of our work may contact the first author (e-mail: Thorsten.Schank@wiso.uni-erlangen.de) for a copy of the Stata do-files used to produce the results reported here.
} 
The dependent variable in our investigation is the log of wages, taken from the IAB Establishment Panel and, alternatively, from the employment statistics. Whereas the IAB panel data just provide information on the total wage bill of an establishment, the information on individual earnings in the employment statistics is more detailed, but it refers only to the income subject to social security contributions (i.e. up to the contribution assessment ceiling of the social security system). This affects about eight percent of all observations in the data set. Not taking account of this phenomenon and applying OLS or standard fixed effects techniques would cause biased estimates. We treat the data problem as a missing data problem and multiply impute the censored wages by draws of a random variable from a truncated distribution. ${ }^{3}$

In multiple imputation (Ml), each value of the unknown missing data $Y_{\text {mis }}$ is replaced by $m$ simulated values $Y_{\text {mis }}^{1}, Y_{\text {mis }}^{2}, \ldots, Y_{\text {mis }}^{m}$. The $m$ (as opposed to one) sets of imputations reflect uncertainty about the true values of the data. After the multiple imputations have been carried out, $m$ completed data-sets (and plausible versions of the real data) exist, each of which can then be analyzed by standard complete-data methods.

The $m$ simulated values are obtained through iterations of two steps: ${ }^{4}(1)$ In the first step, values for the missing information (i.e. for those observations where the wages are censored) are drawn from a truncated distribution. ${ }^{5}$ Based on the uncensored and the imputed data, we then estimate a wage equation by OLS. (2) Using the parameters of this regression, the data posterior distribution can be specified. Based on this distribution, we draw new parameters. In general, we will not be able to use successive iterates because they tend to be correlated (Schafer 1997). Therefore, we repeat steps (1) and (2) ten thousand times and keep the data draws (step 1 ) of every one-thousandth iteration as a new-data set. ${ }^{6}$ Hence, we end up with ten complete data-sets.

\footnotetext{
${ }^{3}$ Multiple imputation has been developed by Rubin (1978) and is explained in Rubin (1996), Schafer (1997) and Rässler, Rubin and Schenker (2004). In the context of censored wages multiple imputation has been proposed and applied by Gartner and Rässler (2005).

${ }^{4}$ Multiple imputations based on Markov chain Monte Carlo techniques are discussed in Schafer (1997). We apply an algorithm of this technique proposed by Gartner and Rässler (2005) in the context of censored data. For a formal presentation, the reader is referred to Gartner and Rässler (2005).

${ }^{5}$ The starting values for the truncated distribution are obtained from a tobit estimation.

${ }^{6}$ For our data, autocorrelation functions of the parameters estimated from 10,000 iterations show that the chain converges and that - for the chosen lag of 1000 - autocorrelation does not cause problems.
} 
The wage equation estimated in the first step is based on all the available information which possibly influences wages. ${ }^{7}$ These include both individual and plant level variables and comprise the following: the age (and its square) of the employee, a gender dummy, qualification dummies, dummies indicating that the employee is married, that he is of foreign nationality, that he works part-time, 98 dummies for the individual profession, the logarithm (and its square) of establishment size, the logarithm of the capital labor ratio, standard working time, a dummy for the existence of overtime work, percentages of female workers, parttime employees, foreign workers and workers with a graduate degree within an establishment, a dummy indicating that the plant has non-zero exports as well as a variable for the export share within total sales, dummies for the economic performance of an establishment, dummies indicating that the establishment applies a bargaining agreement from the sectoral or from the firm level, an index for the state of technology as well as two year, nine federal state and thirteen industry dummies.

In the following sections, we estimate a wage regression for a given specification for each of the ten imputed data sets and obtain ten parameter estimates. The average of these ten estimates yields the Multiple Imputation (MI) point estimate. The standard error of the MI point estimate is composed of a between component (the standard deviation of the ten estimates) and a within component (the average of the ten standard errors). ${ }^{8}$

The main focus of our analysis is on the influence of exports on wages. We can make use of two alternative indicators of exports: First, a dummy variable indicating whether or not a plant has any exports, and second the proportion of exports within total sales. Table 1 reports descriptive statistics for these variables and the samples in our study. From the results using weighted data it follows that one in five manufacturing plants was an exporter in the years covered. This is in line with results from official statistics reporting a share of exporters in all manufacturing plants of 23 percent for 1996 (Günterberg and Wolter 2002, p. 250). It is well known that both the propensity to export and the share of exports in total sales tend to increase with firm size in Germany (see e.g. Wagner 2001). Therefore, the share of employees working in exporting firms is much larger about two thirds in our sample (weighted data). Due to the oversampling of larger firms in the IAB panel (mentioned above) the unweighted figures are much higher

\footnotetext{
${ }^{7}$ Rubin (1996, p. 479) states that "...the advice has always been to include as many variables as possible when doing multiple imputations".

${ }^{8}$ The formulas are presented in Schafer (1997). 
for both the share of exporters in all plants (70 percent) and the share of employees in exporting plants (more than 90 percent). Furthermore, the positive relationship between firm size and the share of exports in total sales, and the oversampling of larger firms in the IAB panel, leads to a proportion of exports in total sales of all exporting firms that is 34 percent in the unweighted data compared to 19 percent in the weighted data.

[Table 1 near here]

On average, exporting firms pay higher wages than non-exporters. According to the sample of establishments from the IAB panel used in our empirical investigation the difference between the average monthly wage per employee working in a firm that does or does not export is 36.6 percent. This raw exporter wage premium is both statistically significant and large from an economic point of view.

Descriptive information on the other variables employed in our analysis are reported in a table in Appendix 2.

\section{Traditional Approach}

We start our econometric investigations with a specification which is very similar to that adopted by Bernard and Jensen (1995) in their seminal article. This should constitute a reasonable basis for comparison. Using aggregate plant data from the IAB establishment panel, we estimate the impact of exports on the monthly wage bill per employee, where we make use of two alternative indicators of exports: first, a dummy variable indicating whether or not a plant has any exports, and second the proportion of exports within total sales. We include as control variables the logarithm of the number of employees and its square, the logarithm of capital per worker ${ }^{9}$, average weekly standard hours and year dummies. Finally, a dummy variable for the existence of paid overtime work takes account of the fact that additional (paid) hours are typically compensated with an overtime premium. ${ }^{10}$ The parameter estimates from an OLS regression are reported in the first (export dummy) and fourth (export proportion) column of Table 2. Ceteris paribus

\footnotetext{
${ }^{9}$ The capital stock in year $t$ is approximated by the average of a plant's investment in the years $t, t$ 1 and $t-2$. If for the years $t, t-1$ and $t-2$, there was only investment information available for one year (and two missing values), the respective (plant-year) observation was dropped from the analysis.

${ }^{10}$ We cannot control for the actual number of overtime hours since a considerable part of the plants in the sample provided no information on this variable.
} 
exporting plants do not pay higher wages than non-exporters. The statistically significant and economically large differential between the average wage paid by exporters and non-exporters mentioned above, therefore, is due to differences in the plant observables included in the empirical model. The export share, however, is positively related with wages. If the proportion of exports in total sales rises by ten percentage points, say, the wage per employee will increase by 1.4 percent. We should also note that the parameters of the control variables show the expected sign and are statistically significant at the 1 percent level.

\section{[Table 2 near here]}

Columns two and five of Table 2 report the estimates of wage regressions which additionally include 13 industry and 9 federal state dummies. While the coefficient on the export dummy remains zero, the impact of the export proportion halves in size, but is still significant. Therefore, the positive relationship between the export share and wages is partly due to between-industry differences. ${ }^{11} \mathrm{Next}$, we control for unobserved plant heterogeneity and include plant fixed effects in the regression. ${ }^{12}$ As can be seen from columns three and six of Table 2, both the coefficients on the export dummy and the export share are now totally insignificant, from which one might conclude that (omitted) plant heterogeneity had been responsible for the positive impact of the export share on wages reported above. However, the fixed effects estimates contain much more noise. The standard error for the coefficient on the export share is three times as large as the respective figure obtained by OLS, and all the control variables are also insignificant.

These results differ considerably from those reported by Bernard and Wagner (1997) in the only other study using German data and a comparable approach: Bernard and Wagner found that exporting or not does make a difference, while the share of exports in total sales does not matter. The coefficient of the exporter dummy variable is statistically significant whether fixed plant effects are controlled for or not. One reason for the different findings of Bernard and Wagner (1997) could be that they relied on census-type data from official statistics (where firms are obliged to report true data) over a longer and different time period (1978-1992)

\footnotetext{
${ }^{11}$ Separate regressions which (are available upon request and) either include industry or federal state dummies show that the industry dummies are responsible for the reduction in the coefficient on the export share.

12 The industry and federal state dummies are dropped again since plants do generally neither change industry nor location and it is impossible to distinguish between misreporting and genuine switchers for those (few) who report different affiliations.
} 
and, therefore, with considerable variation of export status and export share within plants.

\section{Individual Level Wage Regressions}

Plant-level estimations may suffer from aggregation bias since we cannot control for observable and unobservable individual heterogeneity which influence wages. Furthermore, the wage information obtained from plant surveys is per se less detailed and any adjustments for part-time employment and apprentices, for example, can only be approximative. In this section, we present individual level wage regressions based on the linked employer-employee data described in section 2.

We first apply OLS to a model without establishment level variables (except the information on exports), but with individual characteristics which are typically included in the empirical literature on wages. These comprise the following variables, all of which are available from the employment statistics: the age of the employee (and its square), a gender dummy, dummies for the occupational status of the employee (unskilled blue-collar, skilled blue-collar, master craftsman/foreman, white-collar worker), and dummies indicating that the employee is working part-time, is married, is of non-German nationality. Note that both the data for the individual characteristics and the information on earnings are from official statistics, and, therefore, can be considered to be highly reliable.

As can be seen from the first column of Table 3, exporting plants do ceteris paribus pay 2.8 percent higher wages, but the difference is only significant at the 10 percent level. On the other hand, we find again a significant positive relationship between the export share and wages. Raising the proportion of exports in total sales by ten percentage points increases the wage by 1.1 percent. As at the plant-level, including industry and federal state dummies reduces the coefficient on the export variables (columns two and four of Table 3), but (again) the impact of the export share on wages can only partly be attributed to differences between industries.

\section{[Table 3 near here]}

Next, we control for individual level heterogeneity by including person fixed effects. The parameter on the export share is now identified either (i) if a plant changes its 
export share or (ii) if an employee moves to a plant with a different export share than its previous employer (and analogously for the parameter on the export dummy). Note that 827 (or 64.3 percent) of the firms included in our sample exported in each year and 370 (or 28.7 percent) did not export at all, while 80 firms (6.2 percent) changed their exporter status once and 10 firms (0.8 percent) did so twice. 2271 persons (0.2 percent) changed between employers included in our sample once, 20 persons (0.002 percent) did so twice. While the shares of exporter status or employer changers in all firms or persons are rather small, the absolute numbers of cases are large enough to identify the parameters of the export variables included in our empirical models.

Columns three and six report the person fixed effects regression estimates. The difference between exporting and non-exporting plants is effectively zero. The impact of the export share on wages has been reduced again, but is still significant. The reduction of the coefficients (both for the exporting dummy as well as for the export share) when controlling for unobserved individual heterogeneity implies that unobserved worker characteristics are positively correlated with the export behavior. Given the observed and unobserved personnel characteristics, a rise in the proportion of exports in total sales by ten percentage points increases the wage by 0.26 percent.

The coefficients on the export variables might still be biased because of the omission of observed and unobserved plant characteristics. As a next step, we therefore add the same variables which have been used in the plant-level regressions discussed in the previous section. We also include industry and federal state level dummies. The OLS estimates which do not take account of unobserved heterogeneity are reported in the first column of Table 4 (export dummy) and Table 5 (export share). These are best compared to the second and fourth column of Table 3, respectively. It can be observed that the inclusion of the plant characteristics reduces the parameters on the export variables. While the effect of the dummy is zero, the coefficient of the export share is still positive and significant. As before, we control next for unobserved personnel heterogeneity (column 2 of Tables 4 and 5). Compared to conditioning on individual as well as plant observables, the coefficient on the export share falls only slightly from 3.3 to 2.7 percent, while the export dummy remains insignificant. Then, we control for unobserved plant characteristics, but not for unobserved personnel heterogeneity. The estimates of these plant fixed effects regressions, which are identified through variations of the variables within a plant, are reported in column 3 of Tables 4 and 
5. Quite surprisingly, the coefficients on the export variables are almost identical for person and plant fixed effects. ${ }^{13}$

[Tables 4 and 5 near here]

However, the coefficients for both person and plant fixed effects might still be biased - in this particular application by the same amount - because in each case we have controlled only for one side of the labor market. To investigate this, the two types of heterogeneity have to be taken account of at the same time in the regression. Unfortunately, because of movement between plants, there is no transformation which sweeps out both sets of fixed effects simultaneously. This means that person de-meaned (or differenced) firm dummies need to be created and estimated. ${ }^{14}$ If one is not interested in the estimates of the heterogeneity themselves, consistent estimates of the coefficients on the observables can be obtained in a computationally far more straightforward way (see Andrews, Schank and Upward 2004). One simply defines unique worker-firm combinations (or 'spells'). By definition, neither the worker nor the firm unobserved (time-invariant) characteristics vary for a given spell. Therefore, we can sweep out both by applying spell fixed effects. Effectively, this uses only the differences between two consecutive observations if the worker does not change his employer between two periods. ${ }^{15}$

Spell fixed effects estimates are reported in the last column of Tables 4 and 5 . It appears that the parameter estimates on the export variables are identical to person or plant fixed effects. Therefore, we can safely conclude that exporting per se does not matter, but that the export share has a statistically significant impact on wages. An increase in the proportion of exports by 10 percentage points increases the wage by 0.28 percent. This means that an employee working in a plant that exports 40 / 60 / 80 percent of its production earns about 1.12 / 1.68 / 2.24 percent more than an employee in a non-exporting plant, ceteris paribus, i.e. after controlling for observable and unobservable individual and plant characteristics.

In a final step of our empirical exercise we look at blue-collar and white-collar workers separately. The reason for this is that Bernard and Wagner (1997) report

\footnotetext{
${ }^{13}$ This does not hold for the individual level variables and for establishment size.

${ }^{14}$ Alternatively, one could also create and estimate firm de-meaned person dummies, but the dimension of persons is usually much larger than the dimension of firms.

${ }^{15}$ Note that this applies to nearly all persons in our regression sample because only 2,271 persons changed between employers included here once, and 20 did so twice.
} 
in their study using plant level data that the positive exporter wage differential is almost exclusively driven by higher wages of white-collar workers. Separate spell fixed effects estimates for both types of employees are listed in Table 6. It can be seen that the parameter estimates on the export variables are quite similar, but slightly higher for blue-collar workers. As the synopsis in Appendix 1 demonstrates, similar results have been obtained in studies for other countries (see, e.g., Bernard and Jensen 1995, 1999, 2004, and Isgut 2001), although the majority of studies find higher wage premia for white-collar workers.

[Table 6 near here]

\section{Conclusions}

The bottom line of our empirical study on the relationship between exporting and wages in West German manufacturing plants is an affirmative answer to the question in the title - exporters really do pay higher wages. Using linked employeremployee data to control for observable and unobservable individual and plant characteristics in the most comprehensive way possible we observe that wages increase with the share of production firms sell on foreign markets. This ceteris paribus exporter wage premium is neither (unplausibly) large nor negligible working in a plant with, e.g., an export/sales ratio of 50 percent means earning about 1.4 percent more compared to working in an otherwise identical plant that does not export at all.

The positive relationship between wages and the share of exports in total sales is in line with previous findings reported in the literature. Three of the studies for other countries using aggregate firm level data (listed in the synopsis in Appendix 1) look at the role of export shares. Both Liu, Tsou and Hammitt (1999) for Taiwan and Isgut (2001) for Columbia report a positive impact of the export share on wages after controlling for unobservable plant heterogeneity, as do Hansson and Lundin (2004) for Sweden based on plant observables only. None of these studies, however, uses linked employer-employee data, so the results may be biased because neither observed nor unobserved individual characteristics are controlled for. ${ }^{16}$

\footnotetext{
${ }^{16}$ To the best of our knowledge there is only one contemporaneous study on exports and wages based on linked employer-employee data: Milner and Tandrayen (2004) use data for 1993 to 1995 from six African countries (Cameroon, Ghana, Kenya, Tanzania, Zambia and Zimbabwe). They find a positive and significant wage premium for workers in exporting firms, even after controlling for firm and individual characteristics. The positive effect is larger for skilled workers, but positive only
} 
An open question to be considered next is why according to our preferred specification with spell fixed effects (reported in the last column of Table 5) wages tend to increase with the proportion of exports in total sales, ceteris paribus. By construction neither observed nor (time-invariant) unobserved characteristics of the workers or the workplace can matter here. Given that the exporter wage premia are paid voluntarily and that the higher wages paid by more exportintensive plants lead to higher costs, the answer must lie in a positive relationship between wage premia over and above the going wage paid in other firms on the one hand, and success on exports markets that leads to high profits on the other hand.

This said, efficiency wage theories form a natural pool of candidates to answer the question under consideration here. Among the various variants of models (Yellen 1984) the "higher-wages-reduce-turnover" variant seems to be most relevant in the context of German firms and exporting. To see why, remember that Germany is a high-wage country. Labor costs per unit of output are higher in Germany than in other competing highly industrialized countries including the U.S., UK, and Japan (Institut der deutschen Wirtschaft Köln 2004, p.7). High unit labor costs and a strong currency mean that German exporters cannot base their success in international market on low-priced products. Instead, they have to rely on complex high-quality products. To successfully produce this kind of products the tacit knowledge of the experienced workforce is a limiting factor of production. Managers often point to the non-transferable know-how incorporated in the firm's workforce when asked why they still produce in high-cost Germany instead of, say, China or India. ${ }^{17}$ Labor turnover is rather costly in these cases, so firms will be interested to reduce quits. One way to achieve this is to pay a premium above the going wage that a worker could earn in another plant. The higher the export/sales ratio and the share of profits earned on the world market, the more important will an experienced workforce be to secure high quality of products and competitiveness of the firm as a whole, and the higher will be the wage premium paid. ${ }^{18}$

\footnotetext{
for firms that sell inside Africa. The relation between the share of exports in total sales and wages is not investigated in this study, however. Two papers by Gustavsson, Heyman and Sjöholm (2004) and by Martins (2004) use linked employer-employee data to look at the related issue of wage differentials between local and foreign owned firms in Sweden and Portugal, respectively.

${ }^{17}$ For a recent example, see Bernhard Schreier of Heidelberger Druckmaschinen, the world market leader in the production of printing equipment, quoted in Handelsblatt, June 30, 2004, p. 13.

${ }^{18}$ Unfortunately it is not possible to test for a difference in labor turnover due to quits between firms with different export shares and different wage premia paid with the data used here.
} 
A question not discussed here is the direction of causality: Do exporters pay higher wages because they are exporters? Did they pay higher wages before they started to export? Do wages increase faster in firms that started to export than in comparable non-exporting firms? To investigate this important topic in a convincing way linked employer-employee data are needed for a panel that covers at least seven years, and that includes a large number of export starters which can be monitored (at least three years) before and (at least three years) after beginning to export, and which can be compared to (matched) firms that did not start to export (see Wagner 2002 for such a study using plant level panel data). The LIAB data used in our study are not (yet) suited for this kind of study, so the topic of causality is left for future research. 
Table 1: Incidence and Coverage of Exporting Plants.

Manufacturing, Western Germany (Percentages)

\begin{tabular}{|l|c|c|}
\hline & Weighted & Unweighted $^{1}$ \\
\hline Share of exporting plants & 19.1 & 70.6 \\
\hline Employment share of exporting plants & 64.8 & 92.7 \\
\hline $\begin{array}{l}\text { Proportion of exports within total sales of } \\
\text { exporting plants }\end{array}$ & 18.9 & 33.8 \\
\hline
\end{tabular}

Source: IAB Establishment Panel 1995-1997.

${ }^{1}$ Plant level regression sample. 
Table 2: $\quad$ Plant Level Wage Regressions. Manufacturing, Western Germany (Endogenous Variable: Logarithm of Monthly Wage Bill per Employee)

\begin{tabular}{|c|c|c|c|c|c|c|}
\hline Estimation Method & OLS & OLS & $\begin{array}{l}\text { Plant } \\
\text { Fixed } \\
\text { Effects }\end{array}$ & OLS & OLS & $\begin{array}{l}\text { Plant } \\
\text { Fixed } \\
\text { Effects }\end{array}$ \\
\hline \multicolumn{7}{|l|}{ Variables } \\
\hline Exporting plant (1 = yes) & $\begin{array}{l}0.017 \\
{[0.75]}\end{array}$ & $\begin{array}{l}0.005 \\
{[0.23]}\end{array}$ & $\begin{array}{l}0.024 \\
{[0.69]}\end{array}$ & & & \\
\hline $\begin{array}{l}\text { Exports (proportion of total } \\
\text { sales) }\end{array}$ & & & & $\begin{array}{l}0.140 \\
{[4.50]^{\star \star *}}\end{array}$ & $\begin{array}{l}0.067 \\
{[2.14]^{\star \star}}\end{array}$ & $\begin{array}{l}0.026 \\
{[0.28]}\end{array}$ \\
\hline $\begin{array}{l}\text { Logarithm of establishment } \\
\text { size (number of employees) }\end{array}$ & $\begin{array}{l}0.213 \\
{[8.44]^{\star \star \star}}\end{array}$ & $\begin{array}{l}0.239 \\
{[9.35]^{\star \star \star}}\end{array}$ & $\begin{array}{l}-0.236 \\
{[1.13]}\end{array}$ & $\begin{array}{l}0.211 \\
{[8.84]^{\star \star \star}}\end{array}$ & $\begin{array}{l}0.238 \\
{[9.77]^{\star \star \star}}\end{array}$ & $\begin{array}{l}-0.235 \\
{[1.13]}\end{array}$ \\
\hline $\begin{array}{l}\text { Squared logarithm of } \\
\text { establishment size }\end{array}$ & $\begin{array}{l}-0.014 \\
{[6.21]^{\star \star \star}}\end{array}$ & $\begin{array}{l}-0.017 \\
{[7.46]^{\star \star \star}}\end{array}$ & $\begin{array}{l}0.010 \\
{[0.55]}\end{array}$ & $\begin{array}{l}-0.015 \\
{[6.66]^{\star \star \star}}\end{array}$ & $\begin{array}{l}-0.017 \\
{[7.80]^{\star \star \star}}\end{array}$ & $\begin{array}{l}0.010 \\
{[0.55]}\end{array}$ \\
\hline $\begin{array}{l}\text { Logarithm of capital per } \\
\text { worker }\end{array}$ & $\begin{array}{l}0.035 \\
{[4.74]^{\star \star \star}}\end{array}$ & $\begin{array}{l}0.037 \\
{[5.16]^{\star \star \star}}\end{array}$ & $\begin{array}{l}0.012 \\
{[0.83]}\end{array}$ & $\begin{array}{l}0.035 \\
{[4.69]^{\star \star \star}}\end{array}$ & $\begin{array}{l}0.037 \\
{[5.11]^{\star \star \star}}\end{array}$ & $\begin{array}{l}0.012 \\
{[0.82]}\end{array}$ \\
\hline Weekly standard hours & $\begin{array}{l}-0.027 \\
{[4.83]^{\star \star \star}}\end{array}$ & $\begin{array}{l}-0.012 \\
{[1.90]^{\star}}\end{array}$ & $\begin{array}{l}-0.008 \\
{[0.80]}\end{array}$ & $\begin{array}{l}-0.025 \\
{[4.67]^{\star \star \star}}\end{array}$ & $\begin{array}{l}-0.012 \\
{[1.88]^{\star}}\end{array}$ & $\begin{array}{l}-0.008 \\
{[0.81]}\end{array}$ \\
\hline $\begin{array}{l}\text { Paid overtime work in } \\
\text { establishment ( } 1=\text { yes })\end{array}$ & $\begin{array}{l}0.098 \\
{[5.17]^{\star \star \star}}\end{array}$ & $\begin{array}{l}0.076 \\
{[4.24]^{\star \star \star}}\end{array}$ & $\begin{array}{l}0.019 \\
{[0.88}\end{array}$ & $\begin{array}{l}0.097 \\
{[5.13]^{\star \star \star}}\end{array}$ & $\begin{array}{l}0.076 \\
{[4.25]^{\star \star \star}}\end{array}$ & $\begin{array}{l}0.019 \\
{[0.87]}\end{array}$ \\
\hline 13 industry dummies & no & yes $^{\star \star \star}$ & no & no & yes $^{\star \star \star}$ & no \\
\hline 9 federal state dummies & no & yes ${ }^{\star \star \star}$ & no & no & yes ${ }^{\star \star \star}$ & no \\
\hline Constant & $\begin{array}{l}8.264 \\
{[36.42]^{\star \star \star}}\end{array}$ & $\begin{array}{l}7.868 \\
{[28.45]^{\star \star \star}}\end{array}$ & $\begin{array}{l}9.434 \\
{[13.31]^{\star \star \star}}\end{array}$ & $\begin{array}{l}8.232 \\
{[36.49]^{\star \star \star}}\end{array}$ & $\begin{array}{l}7.867 \\
{[28.30]^{\star \star \star}}\end{array}$ & $\begin{array}{l}9.445 \\
{[13.30]^{\star \star \star}}\end{array}$ \\
\hline $\mathrm{R}^{2}$ & 0.337 & 0.414 & 0.025 & 0.343 & 0.415 & 0.025 \\
\hline
\end{tabular}

Source:IAB Establishment Panel 1995-1997. 2,797 observations from 1,287 plants. Regressions include year dummies. Absolute values of t-statistics in brackets. Residuals within plants are allowed to be not independent. $* \star \star \star \star / *$ denote significance at the $1 / 5 / 10$ percent level, respectively. 
Table 3: Individual Level Wage Regressions. Manufacturing, Western Germany (Endogenous Variable: Logarithm of Daily Wage)

\begin{tabular}{|c|c|c|c|c|c|c|}
\hline Estimation Method & OLS & OLS & $\begin{array}{l}\text { Person } \\
\text { Fixed } \\
\text { Effects }\end{array}$ & OLS & OLS & $\begin{array}{l}\text { Person } \\
\text { Fixed } \\
\text { Effects }\end{array}$ \\
\hline \multicolumn{7}{|l|}{ Variables } \\
\hline Exporting plant $(1=$ yes $)$ & $\begin{array}{l}0.028 \\
{[1.80]^{\star}}\end{array}$ & $\begin{array}{l}0.019 \\
{[1.89]^{*}}\end{array}$ & $\begin{array}{l}0.008 \\
{[1.22]}\end{array}$ & & & \\
\hline $\begin{array}{l}\text { Exports (proportion of total } \\
\text { sales) }\end{array}$ & & & & $\begin{array}{l}0.114 \\
{[4.08]^{\star \star \star}}\end{array}$ & $\begin{array}{l}0.071 \\
{[4.39]^{\star \star \star}}\end{array}$ & $\begin{array}{l}0.026 \\
{[2.51]^{\star \star}}\end{array}$ \\
\hline Age of employee (years) & $\begin{array}{l}0.026 \\
{[21.63]^{\star \star \star}}\end{array}$ & $\begin{array}{l}0.024 \\
{[21.03]^{\star \star \star}}\end{array}$ & $\begin{array}{l}0.050 \\
{[11.31]^{\star \star \star}}\end{array}$ & $\begin{array}{l}0.026 \\
{[21.35]^{\star \star \star}}\end{array}$ & $\begin{array}{l}0.024 \\
{[20.84]^{\star \star \star}}\end{array}$ & $\begin{array}{l}0.049 \\
{[11.21]^{\star \star \star}}\end{array}$ \\
\hline $\begin{array}{l}\text { Age of employee squared } \\
\text { (divided by 100) }\end{array}$ & $\begin{array}{l}-0.026 \\
{[19.51]^{\star \star \star}}\end{array}$ & $\begin{array}{l}-0.024 \\
{[18.66]^{\star \star \star}}\end{array}$ & $\begin{array}{l}-0.037 \\
{[11.03]^{\star \star \star}}\end{array}$ & $\begin{array}{l}-0.026 \\
{[19.36]^{\star \star \star}}\end{array}$ & $\begin{array}{l}-0.024 \\
{[18.50]^{\star \star \star}}\end{array}$ & $\begin{array}{l}-0.038 \\
{[11.20]^{\star \star \star}}\end{array}$ \\
\hline $\begin{array}{l}\text { Gender }(1=\text { female) } \\
\text { Professional status: } \\
\text { (reference: unskilled blue- } \\
\text { collar worker) }\end{array}$ & $\begin{array}{l}-0.272 \\
{[38.43]^{\star \star \star}}\end{array}$ & $\begin{array}{l}-0.255 \\
{[52.68]^{\star \star \star}}\end{array}$ & & $\begin{array}{l}-0.270 \\
{[39.00]^{\star \star *}}\end{array}$ & $\begin{array}{l}-0.254 \\
{[51.88]^{\star \star \star}}\end{array}$ & \\
\hline Skilled blue-collar worker & $\begin{array}{l}0.100 \\
{[10.32]^{\star \star \star}}\end{array}$ & $\begin{array}{l}0.089 \\
{[14.73]^{\star \star \star}}\end{array}$ & $\begin{array}{l}-0.003 \\
{[0.61]}\end{array}$ & $\begin{array}{l}0.096 \\
{[10.60]^{\star \star \star}}\end{array}$ & $\begin{array}{l}0.088 \\
{[14.89]^{\star \star \star}}\end{array}$ & $\begin{array}{r}-0.003 \\
{[0.56]}\end{array}$ \\
\hline Master craftsmen, foremen & $\begin{array}{l}0.374 \\
{[22.50]^{\star \star \star}}\end{array}$ & $\begin{array}{l}0.369 \\
{[27.37]^{\star \star \star}}\end{array}$ & $\begin{array}{l}0.038 \\
{[1.14]}\end{array}$ & $\begin{array}{l}0.372 \\
{[22.96]^{\star \star \star}}\end{array}$ & $\begin{array}{l}0.368 \\
{[27.47]^{\star \star \star}}\end{array}$ & $\begin{array}{l}0.039 \\
{[1.17]}\end{array}$ \\
\hline White-collar worker & $\begin{array}{l}0.424 \\
{[53.15]^{\star \star \star}}\end{array}$ & $\begin{array}{l}0.409 \\
{[79.26]^{\star \star \star}}\end{array}$ & $\begin{array}{l}0.051 \\
{[7.33]^{\star \star \star}}\end{array}$ & $\begin{array}{l}0.420 \\
{[56.52]^{\star \star \star}}\end{array}$ & $\begin{array}{l}0.408 \\
{[80.16]^{\star \star \star}}\end{array}$ & $\begin{array}{l}0.051 \\
{[7.31]^{\star \star \star}}\end{array}$ \\
\hline Part-time employee ( 1 = yes) & $\begin{array}{l}-0.233 \\
{[16.17]^{\star \star \star}}\end{array}$ & $\begin{array}{l}-0.246 \\
{[20.10]^{\star \star \star}}\end{array}$ & $\begin{array}{l}-0.144 \\
{[9.21]^{\star \star \star}}\end{array}$ & $\begin{array}{l}-0.235 \\
{[16.75]^{\star \star \star}}\end{array}$ & $\begin{array}{l}-0.246 \\
{[20.25]^{\star \star \star}}\end{array}$ & $\begin{array}{l}-0.144 \\
{[9.19]^{\star \star \star}}\end{array}$ \\
\hline Married employee (1 = yes) & $\begin{array}{l}0.019 \\
{[3.50]^{\star \star \star}}\end{array}$ & $\begin{array}{l}0.022 \\
{[6.83]^{\star \star \star}}\end{array}$ & $\begin{array}{l}0.010 \\
{[1.41]}\end{array}$ & $\begin{array}{l}0.019 \\
{[3.58]^{\star \star \star}}\end{array}$ & $\begin{array}{l}0.022 \\
{[6.74]^{\star \star \star}}\end{array}$ & $\begin{array}{l}0.010 \\
{[1.44]}\end{array}$ \\
\hline Foreign employee (1 = yes) & $\begin{array}{l}-0.001 \\
{[0.14]}\end{array}$ & $\begin{array}{l}-0.014 \\
{[2.97]^{\star \star \star}}\end{array}$ & & $\begin{array}{l}-0.002 \\
{[0.29]}\end{array}$ & $\begin{array}{l}-0.015 \\
{[3.14]^{\star \star \star}}\end{array}$ & \\
\hline 13 industry dummies & no & yes $^{\star \star \star}$ & yes $* \star \star$ & no & yes $* \star \star$ & yes $^{\star \star \star}$ \\
\hline 9 federal state dummies & no & yes $^{\star \star \star}$ & yes ${ }^{\star \star \star}$ & no & yes ${ }^{\star \star \star}$ & yes $^{\star \star \star}$ \\
\hline Constant & $\begin{array}{l}9.024 \\
{[284.0]^{\star \star \star}}\end{array}$ & $\begin{array}{l}9.187 \\
{[239.2]^{\star \star \star}}\end{array}$ & $\begin{array}{l}8.384 \\
{[62.64]^{\star \star \star}}\end{array}$ & $\begin{array}{l}9.011 \\
{[299.0]^{\star \star \star}}\end{array}$ & $\begin{array}{l}9.178 \\
{[246.6]^{\star \star \star}}\end{array}$ & $\begin{array}{l}8.395 \\
{[62.31]^{\star \star \star}}\end{array}$ \\
\hline $\mathrm{R}^{2}$ & 0.58 & 0.63 & 0.10 & 0.59 & 0.63 & 0.10 \\
\hline
\end{tabular}

Source: LIAB 1995-1997. 1,855,034 observations, 918,149 individuals and 1,262 plants. Regressions include year dummies. Absolute values of t-statistics in brackets. Residuals within plants are allowed to be not independent. ${ }^{* \star * / * * / *}$ denote significance at the $1 / 5 / 10$ percent level, respectively. 
Table 4: Individual Level Wage Regressions including Plant Characteristics. Manufacturing, Western Germany

(Endogenous Variable: Logarithm of Daily Wage)

\begin{tabular}{|c|c|c|c|c|}
\hline \multirow[t]{2}{*}{ Estimation Method } & \multirow[t]{2}{*}{ OLS } & \multicolumn{3}{|c|}{ Fixed Effects (FE) } \\
\hline & & Person FE & Plant FE & Spell FE \\
\hline \multicolumn{5}{|l|}{ Variables } \\
\hline Exporting plant (1 = yes) & $\begin{array}{l}-0.005 \\
{[0.66]}\end{array}$ & $\begin{array}{l}0.009 \\
{[1.37]}\end{array}$ & $\begin{array}{l}0.007 \\
{[1.24]}\end{array}$ & $\begin{array}{l}0.009 \\
{[1.35]}\end{array}$ \\
\hline Age of employee (years) & $\begin{array}{l}0.024 \\
{[20.49]^{\star \star \star}}\end{array}$ & $\begin{array}{l}0.052 \\
{[12.62]^{\star \star \star}}\end{array}$ & $\begin{array}{l}0.023 \\
{[22.76]^{\star \star \star}}\end{array}$ & $\begin{array}{l}0.053 \\
{[13.22]^{\star \star \star}}\end{array}$ \\
\hline $\begin{array}{l}\text { Age of employee squared } \\
\text { (divided by 100) }\end{array}$ & $\begin{array}{l}-0.024 \\
{[17.85]^{\star \star \star}}\end{array}$ & $\begin{array}{l}-0.037 \\
{[11.35]^{\star \star \star}}\end{array}$ & $\begin{array}{l}-0.023 \\
{[20.67]^{\star \star \star}}\end{array}$ & $\begin{array}{l}-0.037 \\
{[11.53]^{\star \star \star}}\end{array}$ \\
\hline Gender ( 1 = female $)$ & $\begin{array}{l}-0.249 \\
{[52.63]^{\star \star \star}}\end{array}$ & & $\begin{array}{l}-0.231 \\
{[57.18]^{\star \star \star}}\end{array}$ & \\
\hline $\begin{array}{l}\text { Professional status: } \\
\text { (reference: unskilled blue- } \\
\text { collar worker) }\end{array}$ & & & & \\
\hline Skilled blue-collar worker & $\begin{array}{l}0.089 \\
{[14.69]^{\star \star *}}\end{array}$ & $\begin{array}{l}-0.003 \\
{[0.49]}\end{array}$ & $\begin{array}{l}0.091 \\
{[24.09]^{\star \star \star}}\end{array}$ & $\begin{array}{l}-0.003 \\
{[0.61]}\end{array}$ \\
\hline Master craftsmen, foremen & $\begin{array}{l}0.371 \\
{[25.15]^{\star \star \star}}\end{array}$ & $\begin{array}{l}0.044 \\
{[1.69]^{*}}\end{array}$ & $\begin{array}{l}0.377 \\
{[43.06]^{\star \star \star}}\end{array}$ & $\begin{array}{l}0.045 \\
{[1.85]^{\star}}\end{array}$ \\
\hline White-collar worker & $\begin{array}{l}0.407 \\
{[78.79]^{\star \star \star}}\end{array}$ & $\begin{array}{l}0.052 \\
{[7.69]^{\star \star \star}}\end{array}$ & $\begin{array}{l}0.393 \\
{[82.93]^{\star \star \star}}\end{array}$ & $\begin{array}{l}0.052 \\
{[7.61]^{\star \star \star}}\end{array}$ \\
\hline Part-time employee ( 1 = yes) & $\begin{array}{l}-0.245 \\
{[20.64]^{\star \star \star}}\end{array}$ & $\begin{array}{l}-0.144 \\
{[9.28]^{\star \star \star}}\end{array}$ & $\begin{array}{l}-0.256 \\
{[22.96]^{\star \star \star}}\end{array}$ & $\begin{array}{l}-0.144 \\
{[9.28]^{\star \star \star}}\end{array}$ \\
\hline Married employee (1 = yes) & $\begin{array}{l}0.022 \\
{[8.71]^{\star \star \star}}\end{array}$ & $\begin{array}{l}0.007 \\
{[1.57]}\end{array}$ & $\begin{array}{l}0.029 \\
{[21.88]^{\star \star \star}}\end{array}$ & $\begin{array}{l}0.006 \\
{[1.54]}\end{array}$ \\
\hline Foreign employee ( 1 = yes) & $\begin{array}{l}-0.017 \\
{[3.50]^{\star \star \star}}\end{array}$ & & $\begin{array}{l}-0.022 \\
{[4.98]^{\star \star \star}}\end{array}$ & \\
\hline $\begin{array}{l}\text { Logarithm of establishment } \\
\text { size (number of employees) }\end{array}$ & $\begin{array}{l}0.077 \\
{[3.22]^{\star \star \star}}\end{array}$ & $\begin{array}{l}-0.133 \\
{[1.27]}\end{array}$ & $\begin{array}{l}-0.256 \\
{[2.90]^{\star \star \star}}\end{array}$ & $\begin{array}{l}-0.190 \\
{[1.64]}\end{array}$ \\
\hline $\begin{array}{l}\text { Squared logarithm of } \\
\text { establishment size }\end{array}$ & $\begin{array}{l}-0.004 \\
{[1.82]^{\star}}\end{array}$ & $\begin{array}{l}0.012 \\
{[1.44]}\end{array}$ & $\begin{array}{l}0.020 \\
{[2.77]^{\star \star \star}}\end{array}$ & $\begin{array}{l}0.017 \\
{[1.78]^{\star}}\end{array}$ \\
\hline $\begin{array}{l}\text { Logarithm of capital per } \\
\text { worker }\end{array}$ & $\begin{array}{l}0.016 \\
{[4.13]^{\star \star \star}}\end{array}$ & $\begin{array}{l}0.006 \\
{[2.31]^{\star \star}}\end{array}$ & $\begin{array}{l}0.005 \\
{[2.15]^{\star \star}}\end{array}$ & $\begin{array}{l}0.006 \\
{[2.13]^{\star \star}}\end{array}$ \\
\hline Weekly standard hours & $\begin{array}{l}-0.004 \\
{[1.25]}\end{array}$ & $\begin{array}{l}0.003 \\
{[1.27]}\end{array}$ & $\begin{array}{l}0.004 \\
{[2.00]^{\star \star}}\end{array}$ & $\begin{array}{l}0.004 \\
{[1.50]}\end{array}$ \\
\hline $\begin{array}{l}\text { Paid overtime work in } \\
\text { establishment }(1=\text { yes })\end{array}$ & $\begin{array}{l}0.025 \\
{[3.23]^{\star \star \star}}\end{array}$ & $\begin{array}{l}0.011 \\
{[2.49]^{\star \star}}\end{array}$ & $\begin{array}{l}0.007 \\
{[1.97]^{\star \star}}\end{array}$ & $\begin{array}{l}0.011 \\
{[2.46]^{\star \star}}\end{array}$ \\
\hline 13 industry dummies & yes $^{\star \star \star}$ & yes $^{\star \star \star}$ & no & no \\
\hline 9 federal state dummies & yes ${ }^{\star \star \star}$ & yes $^{\star \star \star}$ & no & no \\
\hline Constant & $\begin{array}{l}8.789 \\
{[60.58]^{\star \star \star}}\end{array}$ & $\begin{array}{l}8.445 \\
{[19.41]^{\star \star \star}}\end{array}$ & $\begin{array}{l}9.718 \\
{[33.81]^{\star \star \star}}\end{array}$ & $\begin{array}{l}8.552 \\
{[21.04]^{\star \star \star}}\end{array}$ \\
\hline $\mathrm{R}^{2}$ & 0.65 & 0.11 & 0.59 & 0.11 \\
\hline
\end{tabular}

Source: LIAB 1995-1997. 1,855,034 observations, 918,149 individuals, 1,262 plants and 920,441 spells. Regressions include year dummies. Absolute values of t-statistics in brackets. Residuals within plants are allowed to be not independent. ${ }^{* \star / * *}$ * denote significance at the $1 / 5 / 10$ percent level, respectively. 
Table 5: Individual Level Wage Regressions including Plant Characteristics. Manufacturing, Western Germany

(Endogenous Variable: Logarithm of Daily Wage)

\begin{tabular}{|c|c|c|c|c|}
\hline \multirow[t]{2}{*}{ Estimation Method } & \multirow[t]{2}{*}{ OLS } & \multicolumn{3}{|c|}{ Fixed Effects (FE) } \\
\hline & & Person FE & Plant FE & Spell FE \\
\hline \multicolumn{5}{|l|}{ Variables } \\
\hline $\begin{array}{l}\text { Exports (proportion of total } \\
\text { sales) }\end{array}$ & $\begin{array}{l}0.033 \\
{[2.08]^{\star \star}}\end{array}$ & $\begin{array}{l}0.027 \\
{[3.15]^{\star \star \star}}\end{array}$ & $\begin{array}{l}0.027 \\
{[3.71]^{\star \star \star}}\end{array}$ & $\begin{array}{l}0.028 \\
{[3.32]^{\star \star \star}}\end{array}$ \\
\hline Age of employee (years) & $\begin{array}{l}0.024 \\
{[20.60]^{\star \star \star}}\end{array}$ & $\begin{array}{l}0.052 \\
{[12.57]^{\star \star \star}}\end{array}$ & $\begin{array}{l}0.023 \\
{[22.77]^{\star \star \star}}\end{array}$ & $\begin{array}{l}0.052 \\
{[13.16]^{\star \star \star}}\end{array}$ \\
\hline $\begin{array}{l}\text { Age of employee squared } \\
\text { (divided by 100) }\end{array}$ & $\begin{array}{l}-0.024 \\
{[17.98]^{\star \star \star}}\end{array}$ & $\begin{array}{l}-0.037 \\
{[11.50]^{\star \star \star}}\end{array}$ & $\begin{array}{l}-0.023 \\
{[20.67]^{\star \star \star}}\end{array}$ & $\begin{array}{l}-0.037 \\
{[11.68]^{\star \star \star}}\end{array}$ \\
\hline Gender ( 1 = female) & $\begin{array}{l}-0.249 \\
{[52.36]^{\star \star \star}}\end{array}$ & & $\begin{array}{l}-0.231 \\
{[57.18]^{\star \star \star}}\end{array}$ & \\
\hline \multicolumn{5}{|l|}{$\begin{array}{l}\text { Professional status: } \\
\text { (reference: unskilled blue- } \\
\text { collar worker) }\end{array}$} \\
\hline Skilled blue-collar worker & $\begin{array}{l}0.089 \\
{[14.71]^{\star \star \star}}\end{array}$ & $\begin{array}{l}-0.002 \\
{[0.45]}\end{array}$ & $\begin{array}{l}0.091 \\
{[24.09]^{\star \star \star}}\end{array}$ & $\begin{array}{l}-0.003 \\
{[0.55]}\end{array}$ \\
\hline Master craftsmen, foremen & $\begin{array}{l}0.371 \\
{[25.36]^{\star \star \star}}\end{array}$ & $\begin{array}{l}0.044 \\
{[1.72]^{\star}}\end{array}$ & $\begin{array}{l}0.377 \\
{[43.07]^{\star \star *}}\end{array}$ & $\begin{array}{l}0.045 \\
{[1.88]^{\star}}\end{array}$ \\
\hline White-collar worker & $\begin{array}{l}0.407 \\
{[79.27]^{\star \star \star}}\end{array}$ & $\begin{array}{l}0.052 \\
{[7.68]^{\star \star \star}}\end{array}$ & $\begin{array}{l}0.393 \\
{[82.94]^{\star \star \star}}\end{array}$ & $\begin{array}{l}0.052 \\
{[7.60]^{\star \star \star}}\end{array}$ \\
\hline Part-time employee ( 1 = yes) & $\begin{array}{l}-0.245 \\
{[20.63]^{\star \star \star}}\end{array}$ & $\begin{array}{l}-0.144 \\
{[9.26]^{\star \star \star}}\end{array}$ & $\begin{array}{l}-0.256 \\
{[22.95]^{\star \star \star}}\end{array}$ & $\begin{array}{l}-0.145 \\
{[9.25]^{\star \star \star}}\end{array}$ \\
\hline Married employee ( 1 = yes) & $\begin{array}{l}0.022 \\
{[8.30]^{\star \star \star}}\end{array}$ & $\begin{array}{l}0.007 \\
{[1.61]}\end{array}$ & $\begin{array}{l}0.029 \\
{[21.94]^{\star \star \star}}\end{array}$ & $\begin{array}{l}0.006 \\
{[1.59]}\end{array}$ \\
\hline Foreign employee (1 = yes) & $\begin{array}{l}-0.017 \\
{[3.53]^{\star \star \star}}\end{array}$ & & $\begin{array}{l}-0.022 \\
{[4.98]^{\star \star \star}}\end{array}$ & \\
\hline $\begin{array}{l}\text { Logarithm of establishment } \\
\text { size (number of employees) }\end{array}$ & $\begin{array}{l}0.075 \\
{[3.22]^{\star \star \star}}\end{array}$ & $\begin{array}{l}-0.130 \\
{[1.27]}\end{array}$ & $\begin{array}{l}-0.254 \\
{[2.96]^{\star \star \star}}\end{array}$ & $\begin{array}{l}-0.187 \\
{[1.67]^{\star}}\end{array}$ \\
\hline $\begin{array}{l}\text { Squared logarithm of } \\
\text { establishment size }\end{array}$ & $\begin{array}{l}-0.004 \\
{[1.84]^{\star}}\end{array}$ & $\begin{array}{l}0.012 \\
{[1.44]}\end{array}$ & $\begin{array}{l}0.019 \\
{[2.82]^{\star \star \star}}\end{array}$ & $\begin{array}{l}0.016 \\
{[1.81]^{\star}}\end{array}$ \\
\hline $\begin{array}{l}\text { Logarithm of capital per } \\
\text { worker }\end{array}$ & $\begin{array}{l}0.016 \\
{[4.00]^{\star \star \star}}\end{array}$ & $\begin{array}{l}0.006 \\
{[2.55]^{\star \star}}\end{array}$ & $\begin{array}{l}0.005 \\
{[2.38]^{\star \star}}\end{array}$ & $\begin{array}{l}0.006 \\
{[2.35]^{\star \star}}\end{array}$ \\
\hline Weekly standard hours & $\begin{array}{l}-0.004 \\
{[1.28]}\end{array}$ & $\begin{array}{l}0.003 \\
{[1.46]}\end{array}$ & $\begin{array}{l}0.004 \\
{[2.25]^{\star \star}}\end{array}$ & $\begin{array}{l}0.004 \\
{[1.72]^{\star}}\end{array}$ \\
\hline $\begin{array}{l}\text { Paid overtime work in } \\
\text { establishment ( } 1=\text { yes) }\end{array}$ & $\begin{array}{l}0.026 \\
{[3.35]^{\star \star \star}}\end{array}$ & $\begin{array}{l}0.011 \\
{[2.54]^{\star \star}}\end{array}$ & $\begin{array}{l}0.007 \\
{[2.02]^{\star \star}}\end{array}$ & $\begin{array}{l}0.011 \\
{[2.53]^{\star \star}}\end{array}$ \\
\hline 13 industry dummies & yes $^{\star \star \star}$ & yes $^{\star \star \star}$ & no & no \\
\hline 9 federal state dummies & yes $^{\star \star \star}$ & yes ${ }^{\star \star \star}$ & no & no \\
\hline Constant & $\begin{array}{l}8.800 \\
{[59.90]^{\star \star \star}}\end{array}$ & $\begin{array}{l}8.430 \\
{[19.91]^{\star \star \star}}\end{array}$ & $\begin{array}{l}9.692 \\
{[34.95]^{\star \star \star}}\end{array}$ & $\begin{array}{l}8.536 \\
{[21.69]^{\star \star \star}}\end{array}$ \\
\hline $\mathrm{R}^{2}$ & 0.65 & 0.11 & 0.59 & 0.11 \\
\hline
\end{tabular}

Source: LIAB 1995-1997. 1,855,034 observations, 918,149 individuals, 1,262 plants and 920,441 spells. Regressions include year dummies. Absolute values of t-statistics in brackets. Residuals within plants are allowed to be not independent. $* \star * / * * /$ denote significance at the 1 / 5 / 10 percent level, respectively. 
Table 6: Individual Level Wage Regressions; Separately for Blue-Collar Workers and White-Collar Workers, Manufacturing, Western Germany (Endogenous Variable: Logarithm of Daily Wage)

\begin{tabular}{|c|c|c|c|c|}
\hline \multirow[t]{2}{*}{ Estimation Method } & \multicolumn{4}{|c|}{ Spell Fixed Effects } \\
\hline & \multicolumn{2}{|c|}{ Blue-Collar Workers } & \multicolumn{2}{|c|}{ White-Collar Workers } \\
\hline \multicolumn{5}{|l|}{ Variables } \\
\hline Exporting plant $(1=$ yes $)$ & $\begin{array}{l}0.009 \\
{[1.22]}\end{array}$ & & $\begin{array}{l}0.008 \\
{[1.86]^{\star}}\end{array}$ & \\
\hline $\begin{array}{l}\text { Exports(proportion of total } \\
\text { sales) }\end{array}$ & & $\begin{array}{l}0.030 \\
{[2.54]^{\star \star}}\end{array}$ & & $\begin{array}{l}0.020 \\
{[3.17]^{\star \star \star}}\end{array}$ \\
\hline Age of employee (years) & $\begin{array}{l}0.043 \\
{[9.64]^{\star \star \star}}\end{array}$ & $\begin{array}{l}0.043 \\
{[9.60]^{\star \star \star}}\end{array}$ & $\begin{array}{l}0.089 \\
{[27.73]^{\star \star \star}}\end{array}$ & $\begin{array}{l}0.089 \\
{[27.18]^{\star \star \star}}\end{array}$ \\
\hline $\begin{array}{l}\text { Age of employee squared } \\
\text { (divided by 100) }\end{array}$ & $\begin{array}{l}-0.031 \\
{[9.06]^{\star \star \star}}\end{array}$ & $\begin{array}{l}-0.031 \\
{[9.14]^{\star \star \star}}\end{array}$ & $\begin{array}{l}-0.068 \\
{[22.33]^{\star \star \star}}\end{array}$ & $\begin{array}{l}-0.068 \\
{[22.58]^{\star \star \star}}\end{array}$ \\
\hline \multicolumn{5}{|l|}{$\begin{array}{l}\text { Professional status: } \\
\text { (reference: unskilled blue } \\
\text { collar worker) }\end{array}$} \\
\hline Skilled blue collar worker & $\begin{array}{l}0.005 \\
{[0.94]}\end{array}$ & $\begin{array}{l}0.005 \\
{[1.02]}\end{array}$ & & \\
\hline Master craftsmen, foremen & $\begin{array}{l}0.061 \\
{[1.95]^{\star}}\end{array}$ & $\begin{array}{l}0.062 \\
{[1.97]^{\star \star}}\end{array}$ & & \\
\hline Married employee (1 = yes) & $\begin{array}{l}0.010 \\
{[1.45]}\end{array}$ & $\begin{array}{l}0.010 \\
{[1.48]}\end{array}$ & $\begin{array}{l}0.003 \\
{[0.80]}\end{array}$ & $\begin{array}{l}0.003 \\
{[0.81]}\end{array}$ \\
\hline $\begin{array}{l}\text { Logarithm of establishment } \\
\text { size (number of employees) }\end{array}$ & $\begin{array}{l}-0.206 \\
{[1.64]}\end{array}$ & $\begin{array}{l}-0.202 \\
{[1.67]^{\star}}\end{array}$ & $\begin{array}{l}-0.066 \\
{[0.96]}\end{array}$ & $\begin{array}{l}-0.065 \\
{[0.96]}\end{array}$ \\
\hline $\begin{array}{l}\text { Squared logarithm of } \\
\text { establishment size }\end{array}$ & $\begin{array}{l}0.019 \\
{[1.92]^{\star}}\end{array}$ & $\begin{array}{l}0.019 \\
{[1.95]^{\star}}\end{array}$ & $\begin{array}{l}0.006 \\
{[1.04]}\end{array}$ & $\begin{array}{l}0.006 \\
{[1.04]}\end{array}$ \\
\hline $\begin{array}{l}\text { Logarithm of capital per } \\
\text { worker }\end{array}$ & $\begin{array}{l}0.005 \\
{[1.40]}\end{array}$ & $\begin{array}{l}0.006 \\
{[1.57]}\end{array}$ & $\begin{array}{l}0.007 \\
{[3.05]^{\star \star \star}}\end{array}$ & $\begin{array}{l}0.007 \\
{[3.26]^{\star \star \star}}\end{array}$ \\
\hline Weekly standard hours & $\begin{array}{l}0.004 \\
{[1.40]}\end{array}$ & $\begin{array}{l}0.004 \\
{[1.53]}\end{array}$ & $\begin{array}{l}0.002 \\
{[1.27]}\end{array}$ & $\begin{array}{l}0.003 \\
{[1.53]}\end{array}$ \\
\hline $\begin{array}{l}\text { Paid overtime work in } \\
\text { establishment ( } 1=\text { yes) }\end{array}$ & $\begin{array}{l}0.010 \\
{[1.73]^{\star}}\end{array}$ & $\begin{array}{l}0.010 \\
{[1.78]^{\star}}\end{array}$ & $\begin{array}{l}0.010 \\
{[3.91]^{\star \star \star}}\end{array}$ & $\begin{array}{l}0.010 \\
{[4.03]^{\star \star \star}}\end{array}$ \\
\hline Constant & $\begin{array}{l}8.730 \\
{[19.50]^{\star \star \star}}\end{array}$ & $\begin{array}{l}8.711 \\
{[20.02]^{\star \star \star}}\end{array}$ & $\begin{array}{l}7.572 \\
{[31.70]^{\star \star \star}}\end{array}$ & $\begin{array}{l}7.567 \\
{[32.52]^{\star \star \star}}\end{array}$ \\
\hline No. of observations & \multicolumn{2}{|c|}{$1,189,469$} & \multicolumn{2}{|c|}{601,250} \\
\hline No. of employees & \multicolumn{2}{|c|}{585,692} & \multicolumn{2}{|c|}{306,229} \\
\hline No. of plants & \multicolumn{2}{|c|}{1,262} & \multicolumn{2}{|c|}{1,204} \\
\hline No. of spells & \multicolumn{2}{|c|}{586,816} & \multicolumn{2}{|c|}{307,314} \\
\hline $\mathrm{R}^{2}$ & 0.09 & 0.10 & 0.12 & 0.12 \\
\hline
\end{tabular}

Source: LIAB 1995-1997. Regressions include year dummies. Absolute values of t-statistics in brackets. Residuals within plants are allowed to be not independent. ${ }^{* *} / * \star / *$ denote significance at the 1 / 5 / 10 percent level, respectively. 
Appendix 1: Synopsis of studies on exporter wage differentials

\begin{tabular}{|c|c|c|c|c|}
\hline $\begin{array}{l}\text { Author(s) } \\
\text { (year of publication) }\end{array}$ & $\begin{array}{l}\text { Country } \\
\text { (period covered) }\end{array}$ & Sample & Wage variable(s) & Important results \\
\hline $\begin{array}{l}\text { Meller } \\
(1995)\end{array}$ & $\begin{array}{l}\text { Chile } \\
(1986-1989)\end{array}$ & $\begin{array}{l}\text { Sample of } 138 \text { export firms } \\
\text { and } 436 \text { non-export firms } \\
\text { from five industries (food, } \\
\text { wine, wood products, } \\
\text { chemicals, basic metal) }\end{array}$ & Median value of average annual wage & $\begin{array}{l}\text { The null hypothesis of equal means for wage levels among export and } \\
\text { non- export firms (for small and large firms separately) is rejected at the } \\
1 \text { per cent level of significance. Workers of export firms have } \\
\text { consistently higher wages than those from non-export firms in all } \\
\text { industries. (Note that a firm was considered an exporter if at least } 30 \text { per } \\
\text { cent of its production was destined for foreign markets; non-exporters } \\
\text { sell only on the domestic market. Firms with less than } 100 \text { workers were } \\
\text { classified as small firms.) }\end{array}$ \\
\hline $\begin{array}{l}\text { Alvarez and López } \\
\text { (2004) }\end{array}$ & $\begin{array}{l}\text { Chile } \\
(1990-1996)\end{array}$ & $\begin{array}{l}\text { 7,132 manufacturing plants } \\
\text { (unbalanced panel) }\end{array}$ & $\begin{array}{l}\text { Average wage, average wage for production } \\
\text { workers and for non-production workers }\end{array}$ & $\begin{array}{l}\text { Controlling for plant size, foreign ownership, 3-digit sector, and year, } \\
\text { exporter premia are } 21 \text { percent for average wages, } 15 \text { percent for } \\
\text { production wages, and } 28 \text { percent for non-production wages. }\end{array}$ \\
\hline $\begin{array}{l}\text { Isgut } \\
(2001)\end{array}$ & $\begin{array}{l}\text { Colombia } \\
(1981-1991)\end{array}$ & $\begin{array}{l}5,956 \text { to } 6,909 \\
\text { manufacturing plants } \\
\text { (unbalanced panel) }\end{array}$ & $\begin{array}{l}\text { Average annual wages for all workers, blue collar } \\
\text { workers, white collar workers, technicians, and } \\
\text { managers }\end{array}$ & $\begin{array}{l}\text { Average annual wages are much higher in exporting plants than in non- } \\
\text { exporting plants by all five measures of wages in all plants and in plants } \\
\text { from three different size classes (less than } 30,30 \text { to } 100 \text {, more than } 100 \\
\text { workers). Exporter wage premia are statistically significant for all wage } \\
\text { measures after controlling for plant size, industry, region, year, } \\
\text { export/sales ratio, and capital per worker. Fixed effects regressions } \\
\text { including the exports/sales ratio, plant size, capital per worker, and year } \\
\text { estimate exporter wage premia between } 1.5 \text { percent (for white collar } \\
\text { workers) and } 3.3 \text { percent (for blue collar workers). }\end{array}$ \\
\hline $\begin{array}{l}\text { Sinani } \\
(2003)\end{array}$ & $\begin{array}{l}\text { Estonia } \\
(1994-1999)\end{array}$ & $\begin{array}{l}\text { 2,335 observations on } \\
\text { manufacturing firms } \\
\text { (unbalanced panel) with } 420 \\
\text { firms in } 1994 \text { and } 303 \text { firms } \\
\text { in } 1999 .\end{array}$ & Average labor costs & $\begin{array}{l}\text { Average labor costs for exporters equal about four times (1994) and } \\
\text { three times (1999) the average labor costs for non-exporters. }\end{array}$ \\
\hline $\begin{array}{l}\text { Bernard and Wagner } \\
\text { (1997) }\end{array}$ & $\begin{array}{l}\text { Germany } \\
\text { [Federal State of } \\
\text { Lower Saxony] } \\
(1978-1992)\end{array}$ & $\begin{array}{l}\text { 4,263 manufacturing plants } \\
\text { in } 1978 \text {; } \\
4,270 \text { manufacturing plants } \\
\text { in } 1992\end{array}$ & $\begin{array}{l}\text { Average annual wage; } \\
\text { average annual production wage; } \\
\text { average annual non-production wage }\end{array}$ & $\begin{array}{l}\text { Average annual wage, production wage and non-production wage is } \\
\text { higher in all plants and in plants with less than } 250 \text { employees in } 1978 \\
\text { and 1992, but not for plants with more than } 250 \text { or more than } 500 \\
\text { employees. Wage differences are much more pronounced for white- } \\
\text { collar workers. Exporter wage premia are in part statistically significant } \\
\text { after controlling for plant size, capital per worker, production hours per } \\
\text { worker, a multi-plant dummy, and industry: the average wage premium } \\
\text { in exporting plants is } 2.6 \text { percent, while blue-collar workers receive no } \\
\text { premium and white-collar workers are paid } 3.3 \text { percent more. Results } \\
\text { including export intensity are similar. In a fixed effects specification } \\
\text { both the premia for average wages and for white-collar wages remain } \\
\text { significant. }\end{array}$ \\
\hline
\end{tabular}




\begin{tabular}{|c|c|c|c|c|}
\hline $\begin{array}{l}\text { Arnold and Hussinger } \\
(2004)\end{array}$ & $\begin{array}{l}\text { Germany } \\
(1992-2000)\end{array}$ & $\begin{array}{l}\text { Unbalanced panel of 2,149 } \\
\text { observations on the firm level } \\
\text { taken from the Mannheim } \\
\text { Innovation Panel covering } \\
\text { the manufacturing sector }\end{array}$ & Wage per employee (exact definition not given) & $\begin{array}{l}\text { The wage per employee for the } 1,260 \text { exporters is } 24.7 \text { percent higher } \\
\text { than the wage paid by the } 889 \text { non-exporters. Note that firms are } \\
\text { considered to be exporters only if they sell at least five percent of their } \\
\text { turnover abroad. }\end{array}$ \\
\hline $\begin{array}{l}\text { Hahn } \\
(2004)\end{array}$ & $\begin{array}{l}\text { Korea } \\
(1990-1998)\end{array}$ & $\begin{array}{l}\text { ca. } 69,000 \text { to } 97,000 \\
\text { manufacturing plants } \\
\text { (unbalanced panel) }\end{array}$ & $\begin{array}{l}\text { Average wage; } \\
\text { average production worker wage; } \\
\text { average non-production worker wage }\end{array}$ & $\begin{array}{l}\text { Average wages are higher in exporting plants than in non-exporting } \\
\text { plants by all three measures of wages in 1990, } 1994 \text { and } 1998 \text {. Exporter } \\
\text { wage premia are statistically significant and high controlling for } \\
\text { industry, region and plant size (in 1998, } 12.5 \text { percent, } 10.5 \text { percent, and } \\
12.0 \text { percent for the three different measures of wages, respectively). }\end{array}$ \\
\hline $\begin{array}{l}\text { Bernard } \\
(1995)\end{array}$ & $\begin{array}{l}\text { Mexico } \\
(1986-1990)\end{array}$ & $\begin{array}{l}\text { 2,370 manufacturing plants } \\
\text { (balanced panel) }\end{array}$ & $\begin{array}{l}\text { Average annual wage and benefits; } \\
\text { average annual production wage; } \\
\text { average annual non-production wage; average } \\
\text { hourly production wage; } \\
\text { average hourly non-production wage; average } \\
\text { annual benefits }\end{array}$ & $\begin{array}{l}\text { Exporting plants pay higher average amounts than non-exporting plants } \\
\text { for all measures of wages and benefits in } 1986 \text { and } 1992 \text {. Exporter } \\
\text { premia are statistically significant after controlling for capital per } \\
\text { worker, hours per worker, size of plant, foreign ownership, white } \\
\text { collar/total employment, industry, state and year. In a fixed-effects } \\
\text { model only the premia for benefits per employee is statistically } \\
\text { significant. However, the number of plants changing from non-exporter } \\
\text { to exporter or vice versa is rather small so the results from the fixed } \\
\text { effects model rely on a very small sample. }\end{array}$ \\
\hline $\begin{array}{l}\text { Zhou } \\
(2003)\end{array}$ & $\begin{array}{l}\text { Mexico } \\
(1986-1990)\end{array}$ & 2,353 manufacturing plants & $\begin{array}{l}\text { Average white-collar wages; } \\
\text { average blue-collar wages; } \\
\text { average earnings including non-wage benefits and } \\
\text { social security contributions but excluding profit } \\
\text { sharing; } \\
\text { average earnings including everything }\end{array}$ & $\begin{array}{l}\text { Average wages are much higher in exporting plants than in non- } \\
\text { exporting plants by all four measures of wages. Exporter wage premia } \\
\text { are statistically significant and high controlling for industry and state; } \\
\text { and controlling for size of firm, capital-labor ratio, white-collar worker } \\
\text { share in total employment, foreign equity participation dummy, } \\
\text { imported machinery share, royalty payment share, total factor } \\
\text { productivity growth, tariff rates on outputs and inputs, and license } \\
\text { requirements on outputs and inputs. Exporter wage premia are } \\
\text { statistically significant and high (between } 7 \text { and } 9 \text { percent) in fixed } \\
\text { effects regressions. }\end{array}$ \\
\hline $\begin{array}{l}\text { Verhoogen } \\
\text { (2003) }\end{array}$ & $\begin{array}{l}\text { Mexico } \\
(1984-2001) \\
(1993-2001)\end{array}$ & $\begin{array}{l}\text { 3,003 manufacturing plants } \\
\text { for } 1993 \text { - } 2001 \text { in a balanced } \\
\text { panel; } \\
3,605 \text { manufacturing plants } \\
\text { for } 1993 \text { - } 2001 \text { in an } \\
\text { unbalanced panel; } \\
\text { 706 plants for } 1984 \text { - } 2001 \text { in } \\
\text { a balanced panel }\end{array}$ & $\begin{array}{l}\text { Average white-collar hourly wage; } \\
\text { average blue-collar hourly wage; } \\
\text { ratio of white-collar / blue-collar wage }\end{array}$ & $\begin{array}{l}\text { Average white-collar and blue-collar wages, and ratio of white-collar to } \\
\text { blue- collar wage higher for exporters than for non-exporters in 1993, } \\
\text { 1997, and } 2001 \text { (balanced panel } 1993 \text { - 2001); no results reported for the } \\
\text { two other panels. }\end{array}$ \\
\hline $\begin{array}{l}\text { De Loecker } \\
\text { (2004) }\end{array}$ & $\begin{array}{l}\text { Slovenia } \\
(1994-2000)\end{array}$ & $\begin{array}{l}\text { 7,915 manufacturing } \\
\text { establishments (unbalanced } \\
\text { panel); } 20,580 \text { observations }\end{array}$ & Average wage & $\begin{array}{l}\text { Controlling for the number of employees, exporters pay } 16.14 \text { percent } \\
\text { higher wages than non-exporters. }\end{array}$ \\
\hline
\end{tabular}




\begin{tabular}{lll}
\hline Farinas and Martin- & Spain & $\begin{array}{l}\text { 10,145 observations on 1,403 Average wage per hour } \\
\text { Marcos }\end{array}$ \\
$(2003)$ & $(1990-1999)$ & $\begin{array}{l}\text { manufacturing plants } \\
\text { (unbalanced panel) }\end{array}$
\end{tabular}

Average wages are higher in exporting firms than in non-exporting firms for all firms, small firms, and large firms in 1990 and 1999; note that differences are small in large firms (0.3 Euro and 0.5 Euro,

respectively). Exporter wage premium is statistically significant and positive (6 percent) controlling for firm size, industry, year, foreign ownership, and firm age.

\begin{tabular}{llll}
\hline $\begin{array}{l}\text { Hansson and Lundin } \\
\text { (2004) }\end{array}$ & $\begin{array}{l}\text { Sweden } \\
(1990-1999)\end{array}$ & $\begin{array}{l}3,275 \text { manufacturing firms } \\
\text { (between 1,565 and 1,820 } \\
\text { each year) in an unbalanced } \\
\text { panel. }\end{array}$ & $\begin{array}{l}\text { Average annual labor costs (including social } \\
\text { security) per employee; } \\
\text { average earning per employee; } \\
\text { average earnings of skilled employees; average } \\
\text { earnings of less-skilled employees }\end{array}$
\end{tabular}

Average wages are significantly higher for all four wage measures in exporting firms than in non-exporting firms in 1990; in 1999, this holds only for skilled employees (while exporting firms had on average lower labor costs per employee). Using pooled data for 1990 to 1999 (15, 262 or 15,413 observations) exporter wage premia are computed controlling for export share, firm size, capital intensity, industry and year dummies; results are positive and statistically significant for average labor costs (wage premium: 1 percent), average earnings per employee (1.5 percent), and average earnings of skilled workers (7 percent), but not for average earnings of less- skilled workers.

\begin{tabular}{llll}
\hline $\begin{array}{l}\text { Aw and Batra } \\
(1999)\end{array}$ & $\begin{array}{l}\text { Taiwan } \\
\text { (1986) }\end{array}$ & $\begin{array}{l}\text { 80,584 firms in ten } \\
\text { manufacturing industries } \\
\text { from the 1986 census }\end{array}$ & $\begin{array}{l}\text { Average annual wage of non-production labor and } \\
\text { of production labor }\end{array}$ \\
& &
\end{tabular}

For all ten industries exporters pay higher wages than non-exporters to both their non-production and production labor. The average crossindustry export wage premium (after controlling for firm size, foreign capital, firm age, multiplant status, and technology investment) is almost 30 percent for non-production workers and 14 percent for production workers.

\begin{tabular}{|c|c|c|c|c|}
\hline $\begin{array}{l}\text { Liu, Tsou and Hammitt } \\
\text { (1999) }\end{array}$ & $\begin{array}{l}\text { Taiwan } \\
(1989-1993)\end{array}$ & $\begin{array}{l}875 \text { plants from electronics } \\
\text { industry (balanced panel) } \\
\text { Information on exports only } \\
\text { available for } 1990 \text { and } 1992\end{array}$ & Average annual wage & $\begin{array}{l}\text { Average annual wage is much higher in exporting plants than in non- } \\
\text { exporting plants in } 1992 \text {. Exporter wage premium is statistically } \\
\text { significant and positive ( } 15.5 \text { percent) in a random effects regression } \\
\text { controlling for capital intensity, ratio of subcontracting revenues to total } \\
\text { sales, and ratio of R\&D expenditure to total sales. }\end{array}$ \\
\hline $\begin{array}{l}\text { Tsou, Liu and Hammitt } \\
\text { (2002) }\end{array}$ & $\begin{array}{l}\text { Taiwan } \\
(1986-1996)\end{array}$ & $\begin{array}{l}\text { Plant level data from the } \\
\text { electrical machinery and } \\
\text { electronics industry; 5,923 } \\
\text { plants in 1986, 8,346 plants }\end{array}$ & Average annual wage & $\begin{array}{l}\text { Average annual wages were significantly higher for exporters than for } \\
\text { non-exporters; the differentials were } 23.8 \text { percent in } 1991 \text { and } 18.6 \\
\text { percent in } 1996 \text {. }\end{array}$ \\
\hline $\begin{array}{l}\text { Greenaway and Yu } \\
\text { (2004) }\end{array}$ & $\begin{array}{l}\text { UK } \\
(1989-1999)\end{array}$ & $\begin{array}{l}461 \text { firms (unbalanced panel) } \\
\text { from the chemical industry; } \\
2,883 \text { observations. Some } \\
\text { results for "other } \\
\text { manufactures" are reported, } \\
\text { too. }\end{array}$ & Average annual wage & $\begin{array}{l}\text { Average annual wages are } 1.5 \text { percent higher for exporters from other } \\
\text { manufacturing, and } 7.6 \text { percent higher for exporters from the chemical } \\
\text { industry. Exporter premia (controlling for industry and time effects) are } \\
4.5 \text { percent and } 6.4 \text { percent, respectively. }\end{array}$ \\
\hline $\begin{array}{l}\text { Bernard and Jensen } \\
\text { (1995) }\end{array}$ & $\begin{array}{l}\text { U.S. } \\
(1976-1987)\end{array}$ & $\begin{array}{l}\text { 193,463 manufacturing } \\
\text { plants (1987 Census of } \\
\text { Manufactures) ca. } 400,000\end{array}$ & $\begin{array}{l}\text { Average annual wage per worker; } \\
\text { average annual wage per production worker; } \\
\text { average annual wage per non-production worker; }\end{array}$ & $\begin{array}{l}\text { All average wages and benefits are higher in exporting plants than in } \\
\text { non- exporting plants of all size classes, and with less than } 250 \\
\text { employees or with } 250 \text { and more employees in } 1987 \text {. Exporter wage }\end{array}$ \\
\hline
\end{tabular}


hours per worker, size of plant, and year.

Bernard and Jensen

(1999)

U.S.

$(1984-1992)$

56,257 manufacturing plants

in 1984

199,258 manufacturing

plants in 1987;

224,009 manufacturing

plants in 1992

\begin{tabular}{lll}
\hline $\begin{array}{l}\text { Bernard and Jensen } \\
\text { (2004) }\end{array}$ & $\begin{array}{l}\text { U.S. } \\
(1984-1992)\end{array}$ & $\begin{array}{l}13,550 \text { manufacturing plants } \\
\text { (balanced panel) }\end{array}$
\end{tabular}

(2004)

$(1984-1992)$

(balanced panel)

Average annual wage;

annual blue-collar wage;

annual white-collar wage

Exporter wage premia are statistically significant after controlling for industry, state, and plant size. Estimates for 1992 are 9.3 percent for average wage, 6.6 percent for production wage, and 4.6 for nonproduction wage.

annual average production wage;

annual average non-production wage
Van Biesebroeck

(2003)

Sub-Saharan Africa:
Burundi, Cameroon,
Cote d'Ivoire,

Cote d'Ivoire,

Ethiopia, Ghana,

Kenya, Tanzania,

Zambia, Zimbabwe

$(1992$ / 1996)

\section{approx. 200 firms and three Average wage;}

production wage;

country except Cote d'Ivoir

(two years) and Burundi and

Ethiopia (one year);

unbalanced panels.
Exporter wage premia are statistically significant after controlling for industry and state in 1984 and 1992; estimates for 1992 are 6.9 percent for average wage and blue-collar wage, and 3.7 percent for white-collar wage.

Exporter wage premia is statistically significant and high (about 40 percent) for average wage after controlling for country, year, industry, location, and plant size. The premia is statistically significant and high (about 33 percent) for non-production wage in a sub-sample with information on it, but not statistically significant for production wage.

Note: The studies are listed in alphabetical order of the country considered; studies covering up to three countries are listed separately for each country, other multi-country studies are listed at the bottom of the table. 
Appendix 2: Descriptive Statistics; Regression Sample (Individual Level), Manufacturing, Western Germany

\begin{tabular}{|c|c|c|c|c|c|c|}
\hline \multirow{2}{*}{ Variables } & \multicolumn{2}{|c|}{ All } & \multicolumn{2}{|c|}{ Blue-Collar Workers } & \multicolumn{2}{|c|}{ White-Collar Workers } \\
\hline & Mean & s.d. & Mean & s.d. & Mean & s.d. \\
\hline \multicolumn{7}{|l|}{$\begin{array}{l}\text { Logarithm of daily wage } \\
\text { (in Pfennigen), }\end{array}$} \\
\hline reported & 9.773 & 0.293 & 9.692 & 0.223 & 9.993 & 0.235 \\
\hline imputed wages & 9.792 & 0.323 & 9.694 & 0.227 & 10.048 & 0.288 \\
\hline \multirow{2}{*}{$\begin{array}{l}\text { Exporting plant }(1=\text { yes) } \\
\text { Exports (proportion of total } \\
\text { sales) }\end{array}$} & 0.394 & 0.236 & 0.391 & 0.230 & 0.403 & 0.248 \\
\hline & 0.925 & 0.263 & 0.931 & 0.254 & 0.915 & 0.278 \\
\hline Age of employee (years) & 40.118 & 10.316 & 39.296 & 10.374 & 41.574 & 10.121 \\
\hline $\begin{array}{l}\text { Age of employee squared } \\
\text { (divided by 100) }\end{array}$ & 17.159 & 8.496 & 16.518 & 8.418 & 18.308 & 8.573 \\
\hline Gender ( 1 = female) & 0.199 & 0.400 & 0.141 & 0.348 & 0.240 & 0.427 \\
\hline \multicolumn{7}{|l|}{$\begin{array}{l}\text { Professional status: } \\
\text { (reference: unskilled blue- } \\
\text { collar worker) }\end{array}$} \\
\hline $\begin{array}{l}\text { Skilled blue-collar } \\
\text { worker }\end{array}$ & 0.272 & 0.445 & 0.425 & 0.494 & 0.000 & 0.000 \\
\hline $\begin{array}{l}\text { Master craftsmen, } \\
\text { foremen }\end{array}$ & 0.023 & 0.150 & 0.036 & 0.186 & 0.000 & 0.000 \\
\hline White-collar worker & 0.324 & 0.468 & 0.000 & 0.000 & 1.000 & 0.000 \\
\hline $\begin{array}{l}\text { Part-time employee } \\
\text { (1 = yes) }\end{array}$ & 0.035 & 0.183 & 0.000 & 0.000 & 0.000 & 0.000 \\
\hline $\begin{array}{l}\text { Married employee } \\
\text { (1 = yes) }\end{array}$ & 0.645 & 0.478 & 0.638 & 0.481 & 0.646 & 0.478 \\
\hline $\begin{array}{l}\text { Foreign employee } \\
\text { (1 = yes) }\end{array}$ & 0.130 & 0.337 & 0.183 & 0.387 & 0.032 & 0.177 \\
\hline $\begin{array}{l}\text { Logarithm of } \\
\text { establishment size }\end{array}$ & 7.486 & 1.285 & 7.489 & 1.294 & 7.499 & 1.262 \\
\hline $\begin{array}{l}\text { Logarithm of } \\
\text { establishment size } \\
\text { squared }\end{array}$ & 57.694 & 19.145 & 57.757 & 19.268 & 57.828 & 18.921 \\
\hline $\begin{array}{l}\text { Logarithm of capital per } \\
\text { worker }\end{array}$ & 9.484 & 0.851 & 9.495 & 0.824 & 9.480 & 0.900 \\
\hline Weekly standard hours & 36.062 & 1.452 & 36.005 & 1.479 & 36.151 & 1.397 \\
\hline $\begin{array}{l}\text { Paid overtime in } \\
\text { establishment ( } 1 \text { = yes) }\end{array}$ & 0.907 & 0.291 & 0.905 & 0.293 & 0.914 & 0.280 \\
\hline \multicolumn{7}{|l|}{$\begin{array}{l}\text { Year dummies (reference: } \\
\text { year = 1995) }\end{array}$} \\
\hline 1996 & 0.306 & 0.461 & 0.301 & 0.459 & 0.316 & 0.465 \\
\hline 1997 & 0.327 & 0.469 & 0.327 & 0.469 & 0.328 & 0.469 \\
\hline \multicolumn{7}{|l|}{ Number of observations: } \\
\hline $\begin{array}{l}\text { total } \\
\text { censored }\end{array}$ & \multicolumn{2}{|c|}{$\begin{array}{l}1,855,034 \\
(224,795)\end{array}$} & \multicolumn{2}{|c|}{$\begin{array}{c}1,189,469 \\
(20,378)\end{array}$} & \multicolumn{2}{|c|}{$\begin{array}{c}601,250 \\
(203,850)\end{array}$} \\
\hline
\end{tabular}

Source: LIAB 1995-1997. 


\section{References}

Abowd, John and Kramarz, Francis. 1999. "The Analysis of Labor Markets using Matched Employer-Employee Data" in: Orley Ashenfelter and David Card (eds.), Handbook of Labor Economics, vol. 3B, Amsterdam: Elsevier Science, 2629-2710.

Alvarez, Roberto and Ricardo A. López. 2004. "Exporting and Performance: Evidence from Chilean Plants." Mimeo. Indiana University, Bloomington, February.

Arnold, Jens Matthias and Katrin Hussinger. 2004. "Export Behavior and Firm Productivity in German Manufacturing. A Firm-level Analysis." Centre for European Economic Research Discussion Paper No. 04-12, Mannheim, January.

Andrews, Martyn, Thorsten Schank and Richard Upward. 2004. "Practical estimation methods for linked employer-employee data", Friedrich-Alexander Universität Erlangen-Nürnberg, Lehrstuhl für Arbeitsmarkt- und Regionalpolitik, Discussion Paper No. 29, September 2004.

Aw, Bee Yan and Geeta Batra. 1999. "Wages, firm size, and wage inequality: How much do exports matter?" in: David B. Audretsch and A. Roy Thurik (eds.), Innovation, Industry Evolution, and Employment. Cambridge, UK: Cambridge University Press, 13-56.

Bender, Stefan, Anette Haas and Christoph Klose. 2000. "The IAB Employment Subsample 1975-1995", Schmollers Jahrbuch / Journal of Applied Social Science Studies 120 (4), 649-662.

Bernard, Andrew B. 1995. "Exporters and Trade Liberalization in Mexico: Production Structure and Performance." mimeo, MIT, Boston, February.

Bernard, Andrew B. and J. Bradford Jensen. 1995. "Exporters, Jobs, and Wages in U.S. Manufacturing: 1976-1987." Brookings Papers on Economic Activity, Microeconomics, 67-119. Washington, DC.

Bernard, Andrew B. and J. Bradford Jensen. 1999. "Exceptional Exporter Performance: Cause, Effect, or Both?" Journal of International Economics 47 (1), 1-25.

Bernard, Andrew B. and J. Bradford Jensen. 2004. "Why Some Firms Export." Review of Economics and Statistics 86(2), 561-569.

Bernard, Andrew B. and Joachim Wagner. 1997. "Exports and Success in German Manufacturing." Weltwirtschaftliches Archiv / Review of World Economics 133 (1), 134-157.

De Loecker, Jan. 2004. "Do Exports Generate Higher Productivity? Evidence from Slovenia." Katholieke Universiteit Leuven, LICOS Centre for Transition Economics, Discussion Paper 151/2004, July.

Farinas, José C. and Ana Martin-Marcos. 2003. "Exporting and Economic Performance: Firm-level Evidence for Spanish Manufacturing." mimeo, Universidad Complutense, Madrid. 
Gartner, Hermann and Susanne Rässler. 2005. "Analyzing the Changing Gender Wage Gap based on Multiple Imputed Right Censored Wages". IAB Discussion Paper. Nürnberg (forthcoming).

Greenaway, David and Zhihong Yu. 2004. "Firm-Level Interactions between Exporting and Productivity: Industry-Specific Evidence." Review of World Economics / Weltwirtschaftliches Archiv 140(3), 376-392.

Günterberg, Brigitte and Hans-Jürgen Wolter. 2002. "Unternehmensgrößenstatistik 2001/2002 -Daten und Fakten." Bonn: Institut für Mittelstandsforschung.

Gustavsson, Patrik, Frederik Heyman and Frederik Sjöholm. 2004. "Foreign Ownership and Wages: Results from Matched Worker - Firm Data." Paper presented at the European Trade Study Group (ETSG) conference in Nottingham, September 9-11.

Hahn, Chin Hee. 2004. "Exporting and Performance of Plants: Evidence from Korean Manufacturing." National Bureau of Economic Research, NBER Working Paper Series No. 10208, January.

Hansson, Pär and Nan Nan Lundin. 2004. "Exports as an Indicator on or Promoter of Successful Swedish Manufacturing Firms in the 1990s." Review of World Economics / Weltwirtschaftliches Archiv 140(3), 415-445.

Institut der deutschen Wirtschaft Köln. 2004. "Standort Deutschland - Ein internationaler Vergleich." Köln: Deutscher Instituts-Verlag.

Isgut, Alberto E.. 2001. "What's Different about Exporters? Evidence from Colombian Manufacturing." Journal of Development Studies 37 (5), June, 57-82.

Kölling, Arnd. 2000. "The IAB-Establishment Panel". Schmollers Jahrbuch / Journal of Applied Social Science Studies 120 (3), 291-300.

Liu, Jin-Tan, Meng-Wen Tsou and James K. Hammitt. 1999. "Export Activity and Productivity: Evidence from the Taiwan Electronics Industry." Weltwirtschaftliches Archiv / Review of World Economics 135 (4), 675-691.

Martins, Pedro S. 2004. "Do Foreign Firms Really Pay Higher Wages? Evidence from Different Estimators." Institute for the Study of Labor IZA DP No. 1388, November.

Meller, Patricio. 1995. "Chilean Export Growth, 1970-1990: An Assessment". In: G. K. Helleiner (Ed.), Manufacturing for Export in the Developing World. Problems and Possibilities. London and New York: Routledge, 21-53.

Milner, Chris and Verena Tandrayen. 2004. "The Impact of Exporting and Export Destination on Manufacturing Wages: Evidence for Sub-Saharan Africa." University of Nottingham, Centre for Research in Economic Development and International Trade, CREDIT Research Paper No. 04/01, March.

Rässler, Susanne, Donald B. Rubin and Nathaniel Schenker. 2004."Imputation". in: M. S. Lewis-Beck, A. Bryman and T. F. Liao (eds.), The SAGE Encyclopedia of Social Science Research Methods, Vol. 2, Thousand Oaks: Sage, 477-481.

Rubin, Don. 1978. "Multiple Imputation in Sample Surveys - A Phenomenological Bayesian Approach to Nonresponse." Proceedings of the Survey Research Methods Sections of the American Statistical Association, 20-34. 
Rubin, Don. 1996. "Multiple Imputation after 18 years." Journal of the American Statistical Association, 19, 473-489.

Schafer, Joseph. 1997. Analysis of Incomplete Multivariate Data. London: Chapman \& Hall.

Sinani, Evis. 2003. "Export Market Participation: The Importance of Sunk Costs and Spillovers." Mimeo, Center for East European Studies, Copenhagen Business School, March.

Tsou, Meng-Wen, Jin-Tan Liu and James K. Hammitt. 2002. "Exporting and Productivity". Mimeo, Harvard School of Public Health, Boston, December.

Van Biesebroeck, Johannes. 2003. "Exporting raises Productivity in Sub-Saharan African Manufacturing Plants." National Bureau of Economic Research NBER Working Paper 10020, October.

Verhoogen, Eric. 2003. "Trade, Quality Upgrading and Wage Inequality in the Mexican Manufacturing Sector: Theory and Evidence from an Exchange-Rate Shock." mimeo, University of California, Berkeley.

Wagner, Joachim. 2001. "A Note on the Firm Size - Export Relationship." Small Business Economics, 17, 229-237.

Wagner, Joachim. 2002. "The causal effects of exports on firm size and labor productivity: First evidence from a matching approach." Economics Letters 77, 287-292.

Yellen, Janet. 1984. "Efficiency Wage Models of Unemployment." American Economic Review Papers and Proceedings 74, 200-205.

Zhou, Li. 2003. "Why do Exporting Firms Pay Higher Wages?" mimeo, Emory University, Atlanta. 